\title{
Horizontal String Blossom Thinner Reduces Labor Input and Increases Fruit Size in Peach Trees Trained to Open-center Systems
}

\author{
T. Auxt Baugher ${ }^{1,3}$, J.R. Schupp ${ }^{2}$, K.M. Lesser ${ }^{1}$, and \\ K. Hess-Reichard ${ }^{2}$
}

Additional Index words. Prunus persica, mechanical bloom thinning, crop load management, quality, set, efficiency, stone fruit

SUMMARY. Hand thinning of fruit is among the most labor-intensive orchard practices and consequently contributes significantly to peach (Prunus persica) production costs. Research reported in 2008 on a string blossom thinner for vertical tree canopies demonstrated that this new mechanical method has potential to favorably impact grower profitability by reducing labor requirement and by improving fruit size and quality. A string thinner prototype for open-center tree canopies was tested in six orchards in 2008. Peach blossom removal in upper canopy regions ranged from $23 \%$ to $69 \%$ with the new string thinner oriented in a horizontal or inclined position to thin the tops of vase-shaped trees. Optimal thinning with the horizontal string thinner was with a $2.0 \mathrm{~km} \cdot \mathrm{h}^{-1}$ tractor speed, reducing peach crop load by an average of $47 \%$, reducing follow-up hand thinning time $32 \%$, and increasing fruit in higher market size categories $22 \%$ to $31 \%$. Net economic impact (realized economic savings) of mechanical thinning at $2.0 \mathrm{~km} \cdot \mathrm{h}^{-1}$ versus hand thinning alone ranged from $\$ 799$ to $\$ 911$ per hectare. Total yield was sometimes reduced by string thinner treatments; however, high-market-value yields were comparable across treatments. Two combination treatments-mechanical thinning followed by hand blossom thinning and thinning with a horizontal followed by a vertical string thinner-suggested additional strategies for achieving the most desirable thinning results.

$\mathrm{H}$ and thinning of stone fruit crops is labor-intensive and labor availability is a major concern for producers. Eastern growers commonly spend $\$ 350$ to $\$ 600$ per acre for hand thinning peaches (Penn State Cooperative Extension,

We greatly appreciate the financial support of the Penn State College of Agriculture Seed Grant Program, the Pennsylvania Department of Community and Economic Development First Industries Program, the State Horticultural Association of Pennsylvania Extension Committee, the Washington Tree Fruit Research Commission, and the Pennsylvania Peach and Nectarine Board.

We acknowledge the valuable contributions of $\mathrm{M}$. Reid, C. Musselman, A. Leslie, K. Ellis, E. Moore, C. Witt, M. Tindall, T. Salada, E. Anderson, F. Showers, T. Baker, K. Mickley, B. Jarjour, C. Sollenberger, M. Price, A. Betz, S. Betz, D. Kilmer, J. Cline, S. Aguilar, J. Lott, D. Kuhn, S. Kuhn, D. Mickey, J. Mickey, D. Wenk, B. Wenk, J. Wenk, E. Rankin, A. Dias, C. Baugher, D. Lott, and C. McCleaf.

Mention of a trademark, proprietary product, or vendor does not constitute a guarantee or warranty of the product and does not imply its approval to the exclusion of other products or vendors that also may be suitable.

${ }^{1}$ Pennsylvania State Cooperative Extension, Adams County, 670 Old Harrisburg Road, Gettysburg, PA 17325

${ }^{2}$ Department of Horticulture, Fruit Research and Extension Center, 290 University Drive, Pennsylvania State University, Biglerville, PA 17307

${ }^{3}$ Corresponding author. E-mail: tab36@psu.edu.
2008; G.L. Reighard, personal communication). California peach producers spent an average of $\$ 1000 /$ acre in 2008 with extremes of $\$ 1500 /$ acre (R. Hudgins, personal communication). Oregon and Washington producers reported that 2008 thinning costs in fresh market peaches were $\$ 700$ to $\$ 1000$ per acre ( $R$. Orozco, personal communication).

A mechanical string thinner designed to thin apple (Malus $\times$ domestica) blossoms in organic orchards was tested on peach trees for the first time in 2007 (Schupp et al., 2008). The new mechanical thinning strategy demonstrated greater predictability than chemical thinning (Baugher et al., 2008). Because the effects of physical removal are immediately visible, the level of crop removal can be estimated by comparing pre- and post-thinning flower counts. Therefore, a grower can assess the level of crop removal and adjust the machinery to increase or reduce thinning as needed. Likewise, the string blossom thinner enables the grower to selectively thin only portions of the canopy, leaving sections with low blossom density nonthinned.

Three years of research on chemical thinners (Baugher et al., 2008) demonstrated that while the treatments generally increased fruit size, they were inconsistent in reducing follow-up hand thinning requirement. Hand blossom thinning and thinning with a rope curtain also were evaluated in this trial. The two mechanical treatments were more consistent than chemical thinning; however, hand blossom thinning was costly and the rope curtain removed too many blossoms in the tops of the tree canopies. The string blossom thinning research conducted by Schupp et al. (2008) demonstrated that mechanical thinning effectively reduces crop load, as well as reducing labor costs and increasing fruit size beyond that achieved with conventional hand thinning. Mechanical thinners reduced peach crop load an average of $36 \%$, decreased follow-up hand thinning time by $20 \%$ to $42 \%$, and increased fruit in high-marketvalue size categories by $35 \%$. The net economic impact (realized economic savings) of mechanical thinning versus hand thinning alone ranged from $\$ 175$ to $\$ 1966$ per hectare.

The string thinner evaluated in 2007 was designed to thin narrow vertical canopies and therefore was evaluated on peach trees trained to perpendicular V or quad V systems. As many peach orchards are trained to open-center or vase systems, we decided to test an over-tree horizontal string thinner prototype in 2008. The

\begin{tabular}{llll}
\hline $\begin{array}{l}\text { Units } \\
\text { To convert U.S. to SI, } \\
\text { multiply by }\end{array}$ & U.S. unit & SI unit & $\begin{array}{l}\text { To convert SI to U.S., } \\
\text { multiply by }\end{array}$ \\
\hline 0.4047 & acre(s) & $\mathrm{ha}$ & 2.4711 \\
0.3048 & $\mathrm{ft}$ & $\mathrm{m}$ & 3.2808 \\
2.54 & inch(es) & $\mathrm{cm}$ & 0.3937 \\
25.4 & inch(es) & $\mathrm{mm}$ & 0.0394 \\
6.4516 & inch & $\mathrm{cm}^{2}$ & 0.1550 \\
0.4536 & lb & $\mathrm{kg}$ & 2.2046 \\
1.1209 & lb/acre & $\mathrm{kg} \cdot \mathrm{ha}^{-1}$ & 0.8922 \\
1.6093 & mph & $\mathrm{km} \cdot \mathrm{h}^{-1}$ & 0.6214
\end{tabular}


objectives of this research were to compare the efficacy of the horizontal string blossom thinner in traditional vase-shaped peach canopies relative to conventional hand thinning at 35 to $40 \mathrm{~d}$ after bloom (DAFB) and to evaluate several labor-efficient bloom-thinning methods in various combinations.

\section{Materials and methods}

MECHANICAL STRING THINNER DESCRIPTION. The horizontal string thinner prototype was a modification of a vertical rotating string thinner (Darwin 300; Fruit-Tec, Deggenhausertal, Germany) designed by Hermann Gessler, a German grower, to remove apple blossoms in organic orchards (Bertschinger et al., 1998). Whereas the original string thinner had a vertical frame that tilts $30^{\circ}$ in either direction from the center, the prototype string thinner had a horizontal frame that tilts $30^{\circ}$ downward or upward (Fig. 1). The string thinner evaluated in 2007 had a 3.0-m-long spindle and the prototype had a 2.0$\mathrm{m}$-long spindle. Attached to the spindle were rows of steel plates securing plastic cords that each measured 50 $\mathrm{cm}$ long. The spindle was turned by a hydraulic motor, and the speed was adjusted by a control valve. The

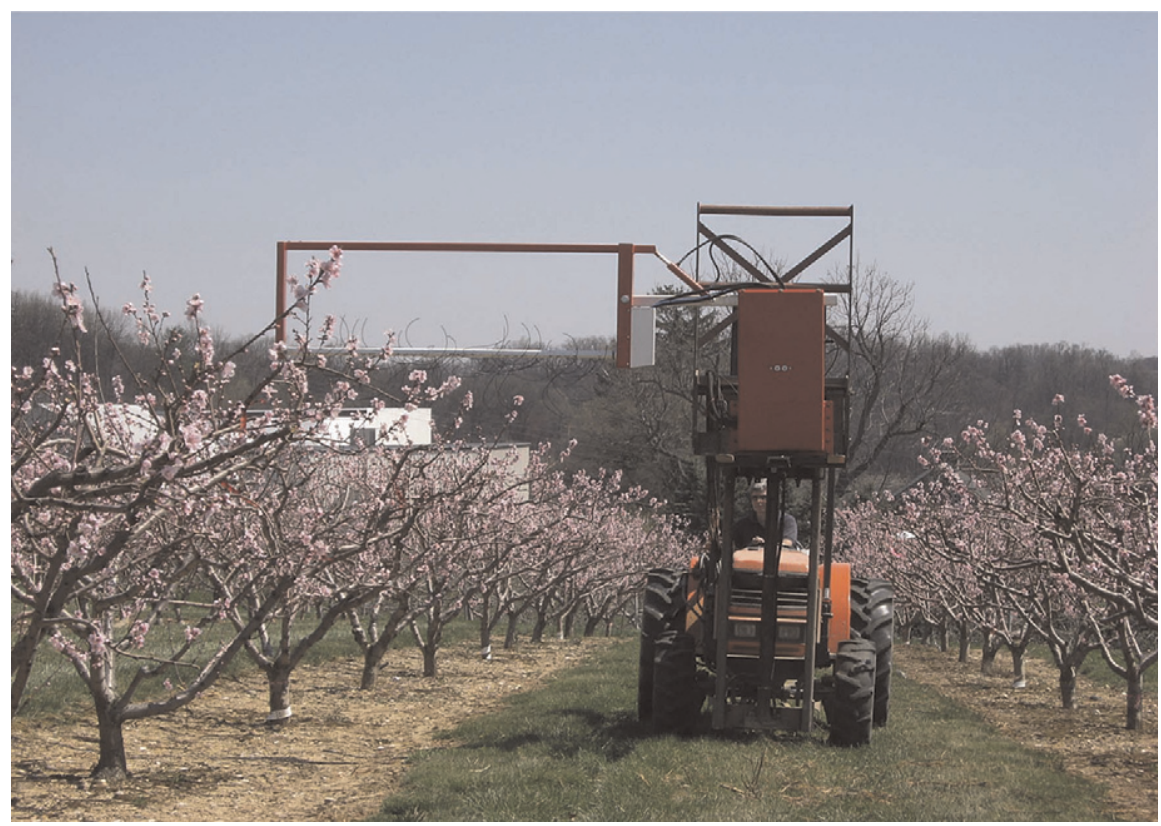

Fig. 1. Horizontal string blossom thinner prototype evaluated on open-centertrained peach trees. The height and angle of the horizontal frame are adjustable to conform to the height and inclination of the tree canopy, and the intensity of thinning is adjustable by changing the number of strings, the rotation speed, and the tractor speed.

height and angle of the horizontal frame were adjustable to conform to the height and inclination of the tree canopy, and the intensity of thinning was adjustable by changing the number of strings, the rotation speed, and the tractor speed.

COMMERCIAL ORCHARD TRIALS WITH THE HORIZONTAL STRING THINNER IN VASE-SHAPED CANOPIES. Trials with the horizontal string blossom thinner prototype were conducted in 2008 in six Pennsylvania orchards trained to open-center systems. Tree architecture included three to five scaffolds, and tree height and spread averaged 6 and $8 \mathrm{ft}$, respectively. The cultivars were Snow Giant, Loring, Cresthaven, Rising Star, John Boy, and Harrow Diamond. The string thinner configuration comprised two rows of plates on opposite sides of the spindle securing 144 cords arranged in alternating patterns of six strings on and six strings off. The string thinner spindle was operated at $200 \mathrm{rpm}$. The thinner was powered hydraulically by a tractor and was driven through orchard rows at $4.0 \mathrm{~km} \cdot \mathrm{h}^{-1}$, as in 2007 trials with the vertical string thinner, or at 2.0 $\mathrm{km} \cdot \mathrm{h}^{-1}$. The experimental design in each trial was a randomized complete block, with six blocks and four-tree plots. Data were collected from two center trees in each plot. The mechanical treatments in all trials were compared with hand thinning at 35 to 40 DAFB and, in one trial, to no thinning. In four trials, blossom-thinning treatments currently used by grower cooperators-rope thinning or hand blossom removal-were included as treatments (techniques described in Baugher et al., 1991). The treatment combinations of the horizontal thinner on the tops of the trees followed by the vertical string thinner on the sides of the trees and the horizontal thinner followed by hand blossom thinning were included in three trials. String thinning was performed at $60 \%$ or $80 \%$ full bloom (FB) in five orchard blocks and at pink in one orchard block with an early-maturing cultivar.

Flower density and crop load were determined on one pretagged scaffold on each of the test trees. Blossom removal with mechanical thinners was evaluated by counting all or a section of blossoms in the upper and lower canopy regions of the tagged scaffold immediately before and after thinning. Reduction in fruit set was evaluated the day of thinning and again following physiological drop (35-40 DAFB) by calculating number of blossoms or fruit per limb cross-sectional area in the upper canopy and the lower canopy, and where practical (based on tree architecture) counts were determined for the entire scaffold. All trees were uniformly hand thinned by growers to commercial levels, during which follow-up hand thinning time was recorded. At harvest, a sample of 40 firm-ripe fruit collected from the center trees in each plot was evaluated for mean fruit diameter and fruit size distribution. In 'Loring', fruit weight per tree per harvest date was determined, and in 'Snow Giant' and 'John Boy', yields were calculated from fruit per scaffold and percentage of size distribution at the first major harvest date. All data were subjected to an analysis of variance and treatments were separated using Fisher's protected least significant difference test.

Economic cost/benefit analyses were performed to evaluate the potential impact of each thinning treatment on fruit returns. Mechanical thinning costs, based on a 15-year useful life of equipment and $8 \%$ interest rate, averaged $\$ 66.05 /$ ha for the 
string thinner, including tractor cost $(\$ 12.00 / \mathrm{h})$ and labor $(\$ 12.00 / \mathrm{h})$. Realized economic savings were calculated from follow-up hand thinning time and fruit size distribution experimental comparisons and from average yields reported by grower cooperators. Prices for the various size categories for each cultivar were obtained from the U.S. Department of Agriculture (2008).

\section{Results and discussion}

FLOWER DENSITY AND FRUIT SET RESPONSES. The first two trials with the horizontal string thinner were conducted at a tractor speed of 4.0 $\mathrm{km} \cdot \mathrm{h}^{-1}$ on 'John Boy' and 'Harrow
Diamond', and flower removal ranged from $5 \%$ to $34 \%$ in lower canopy and $23 \%$ to $51 \%$ in upper canopy regions of a scaffold. In the 'Loring' trial, the $4.0 \mathrm{~km} \cdot \mathrm{h}^{-1}$ tractor speed was compared with a $2.0 \mathrm{~km} \cdot \mathrm{h}^{-1}$ speed, and thinning increased at the reduced speed (Table 1). The remaining trials were conducted at $2.0 \mathrm{~km} \cdot \mathrm{h}^{-1}$, and blossom removal ranged from $33 \%$ to $51 \%$ in lower canopy and $48 \%$ to $69 \%$ in upper canopy regions. A slower travel speed was needed on opencenter compared with $\mathrm{V}$-trained trees, as they had a more complex framework of branching that required more frequent adjustment of spindle position to keep it in close proximity to the canopy without striking structural limbs.

The string thinner reduced flower density (flowers per square centimeter of limb cross-sectional area) compared with the nonthinned control in the upper canopies of all cultivars except the Harrow Diamond thinned at $4.0 \mathrm{~km} \cdot \mathrm{h}^{-1}$ (Table $\mathrm{l}$ ). The thinner reduced flower density in the lower canopies of all cultivars except the Loring and John Boy thinned at 4.0 $\mathrm{km} \cdot \mathrm{h}^{-1}$ and the Rising Star that had a deeper canopy than the other cultivars. Crop density (fruit per square centimeter of limb cross-sectional area), measured at 35 to 40 DAFB and before follow-up hand thinning,

Table 1. Peach blossom thinning and fruit set response to mechanical and hand thinning treatments in six open-center peach system trials in 2008.

\begin{tabular}{|c|c|c|c|c|c|c|}
\hline \multirow[b]{2}{*}{ Thinning treatment $\mathrm{t}^{\mathrm{z}}$} & \multicolumn{3}{|c|}{$\begin{array}{c}\text { Flower density after } \\
\text { thinning (flowers } / \mathrm{cm}^{2} \\
\text { limb-cross-sectional area) }\end{array}$} & \multicolumn{3}{|c|}{$\begin{array}{c}\text { Crop load (density) } \\
35 \text { DAFB }^{\mathrm{x}}\left(\text { fruit } / \mathrm{cm}^{2}\right. \\
\text { limb-cross-sectional area) }\end{array}$} \\
\hline & $\begin{array}{l}\text { Upper } \\
\text { canopy }\end{array}$ & $\begin{array}{l}\text { Lower } \\
\text { canopy }\end{array}$ & Scaffold & $\begin{array}{l}\text { Upper } \\
\text { canopy }\end{array}$ & $\begin{array}{l}\text { Lower } \\
\text { canopy }\end{array}$ & Scaffold \\
\hline & \multicolumn{6}{|c|}{ 'Snow Giant' } \\
\hline Horizontal string thinner, $60 \% \mathrm{FB}$ & $10.6 \mathrm{a}^{\mathrm{w}}$ & $16.3 \mathrm{a}$ & $-^{\mathrm{v}}$ & $4.6 \mathrm{a}$ & $2.4 \mathrm{ab}$ & - \\
\hline $\begin{array}{l}\text { Horizontal, } 2.0 \mathrm{~km} \cdot \mathrm{h}^{-1}+\text { vertical, } 4.0 \mathrm{~km} \cdot \mathrm{h}^{-1} \\
\text { string thinners, } 60 \% \mathrm{FB}\end{array}$ & $4.6 \mathrm{a}$ & $10.4 \mathrm{a}$ & - & $2.2 \mathrm{a}$ & $2.2 \mathrm{a}$ & - \\
\hline \multirow[t]{2}{*}{ Hand-thinned control, 35 DAFB } & $21.1 \mathrm{~b}$ & $27.5 \mathrm{~b}$ & - & $9.1 \mathrm{~b}$ & $2.6 \mathrm{~b}$ & - \\
\hline & \multicolumn{6}{|c|}{ 'Loring' } \\
\hline Horizontal string thinner, $4.0 \mathrm{~km} \cdot \mathrm{h}^{-1}, 60 \% \mathrm{FB}$ & $22.9 \mathrm{ab}$ & $7.6 \mathrm{~b}$ & $14.5 \mathrm{~b}$ & $18.2 \mathrm{~b}$ & $3.9 \mathrm{a}$ & $9.2 \mathrm{bc}$ \\
\hline Horizontal string thinner, $2.0 \mathrm{~km} \cdot \mathrm{h}^{-1}, 60 \% \mathrm{FB}$ & $13.3 \mathrm{a}$ & $4.9 \mathrm{a}$ & $9.4 \mathrm{a}$ & $7.2 \mathrm{a}$ & $3.0 \mathrm{a}$ & $5.5 \mathrm{a}$ \\
\hline Hand-thinned control, 35 DAFB & $35.2 \mathrm{c}$ & $7.7 \mathrm{~b}$ & $21.8 \mathrm{c}$ & $17.4 \mathrm{~b}$ & $4.5 \mathrm{a}$ & $11.7 \mathrm{c}$ \\
\hline \multirow[t]{2}{*}{ Nonthinned control } & $26.1 \mathrm{bc}$ & $7.9 \mathrm{~b}$ & $16.8 \mathrm{~b}$ & $13.7 \mathrm{ab}$ & $3.8 \mathrm{a}$ & $8.3 \mathrm{ab}$ \\
\hline & \multicolumn{6}{|c|}{ 'Cresthaven' } \\
\hline Horizontal string thinner, $60 \% \mathrm{FB}$ & $3.1 \mathrm{a}$ & $1.7 \mathrm{a}$ & $3.4 \mathrm{a}$ & $0.5 \mathrm{a}$ & $0.4 \mathrm{a}$ & $0.7 \mathrm{a}$ \\
\hline Hand blossom thinned, $60 \% \mathrm{FB}$ & $2.8 \mathrm{a}$ & $1.3 \mathrm{a}$ & $2.9 \mathrm{a}$ & $0.7 \mathrm{a}$ & $0.4 \mathrm{a}$ & $0.8 \mathrm{a}$ \\
\hline \multirow[t]{2}{*}{ Hand-thinned control, 35 DAFB } & $9.7 \mathrm{~b}$ & $4.2 \mathrm{~b}$ & $10.0 \mathrm{~b}$ & $1.6 \mathrm{~b}$ & $0.6 \mathrm{a}$ & $1.6 \mathrm{~b}$ \\
\hline & \multicolumn{6}{|c|}{ 'Rising Star' } \\
\hline Horizontal string thinner, pink & $11.8 \mathrm{a}$ & $21.5 \mathrm{~b}$ & - & $3.0 \mathrm{ab}$ & $4.7 \mathrm{bc}$ & - \\
\hline $\begin{array}{l}\text { Horizontal string thinner }+ \text { hand } \\
\text { blossom thinned, pink }\end{array}$ & $8.9 \mathrm{a}$ & $9.4 \mathrm{a}$ & - & $1.5 \mathrm{a}$ & $2.2 \mathrm{a}$ & - \\
\hline Rope thinner, $80 \% \mathrm{FB}$ & $19.0 \mathrm{~b}$ & $13.0 \mathrm{a}$ & - & $5.8 \mathrm{~b}$ & $3.3 \mathrm{ab}$ & - \\
\hline \multirow[t]{2}{*}{ Hand-thinned control, 35 DAFB } & $25.4 \mathrm{c}$ & $21.6 \mathrm{~b}$ & - & $5.7 \mathrm{~b}$ & $5.4 \mathrm{c}$ & - \\
\hline & \multicolumn{6}{|c|}{ 'John Boy' } \\
\hline Horizontal string thinner, $4.0 \mathrm{~km} \cdot \mathrm{h}^{-1}, 80 \% \mathrm{FB}$ & $6.1 \mathrm{a}$ & $3.4 \mathrm{~b}$ & $8.6 \mathrm{ab}$ & $3.2 \mathrm{a}$ & $1.8 \mathrm{~b}$ & $4.6 \mathrm{ab}$ \\
\hline $\begin{array}{l}\text { Horizontal string thinner }+ \text { hand } \\
\text { blossom thinned, } 80 \% \mathrm{FB}\end{array}$ & $5.7 \mathrm{a}$ & $1.5 \mathrm{a}$ & $5.7 \mathrm{a}$ & $2.8 \mathrm{a}$ & $0.8 \mathrm{a}$ & $2.9 \mathrm{a}$ \\
\hline \multirow[t]{2}{*}{ Hand-thinned control, 35 DAFB } & $11.9 \mathrm{~b}$ & $3.9 \mathrm{~b}$ & $11.9 \mathrm{~b}$ & $5.1 \mathrm{~b}$ & $2.0 \mathrm{~b}$ & $5.6 \mathrm{~b}$ \\
\hline & \multicolumn{6}{|c|}{ 'Harrow Diamond' } \\
\hline Horizontal string thinner, $4.0 \mathrm{~km} \cdot \mathrm{h}^{-1}, 60 \% \mathrm{FB}$ & $14.8 \mathrm{ab}$ & $25.1 \mathrm{a}$ & - & $9.3 \mathrm{ab}$ & $16.9 \mathrm{a}$ & - \\
\hline Rope thinner, $80 \% \mathrm{FB}$ & $13.0 \mathrm{a}$ & $36.9 \mathrm{ab}$ & - & $7.5 \mathrm{a}$ & $24.3 \mathrm{ab}$ & - \\
\hline Hand-thinned control, 35 DAFB & $20.5 \mathrm{~b}$ & $48.1 \mathrm{~b}$ & - & $12.2 \mathrm{~b}$ & $32.6 \mathrm{~b}$ & - \\
\hline
\end{tabular}


followed a similar trend with the exception that there were fewer differences in lower canopy regions (Table 1 ). Mechanical thinning was no different in performance to hand blossom thinning, while comparisons to a rope thinner were variable depending on canopy depth. Flower density and fruit set responses improved when mechanical thinning was followed by hand blossom thinning or thinning with the vertical string thinner.

FOLLOW-UP HAND THINNING COMPARISONS. At $2.0 \mathrm{~km} \cdot \mathrm{h}^{-1}$, the horizontal string thinner prototype reduced follow-up hand thinning time by $30 \%$ to $34 \%$ compared with green fruit thinning alone (handthinned control, 35-40 DAFB) (Table 2). At $4.0 \mathrm{~km} \cdot \mathrm{h}^{-1}$, the prototype thinner did not reduce follow-up hand thinning time in two of three cultivars. The rope thinner did not

Table 2. Follow-up hand thinning time required in mechanical and hand thinning treatments in six open-center peach system trials in 2008.

\begin{tabular}{lc}
\hline Hand thinning at \\
Thinning treatment $^{\mathrm{z}}$ & 35-40 DAFB $^{\mathrm{z}}\left(\mathrm{h} \cdot \mathrm{ha}^{-1}\right)^{\mathrm{y}}$ \\
\hline
\end{tabular}

Horizontal string thinner, $60 \% \mathrm{FB}$

Horizontal, $2.0 \mathrm{~km} \cdot \mathrm{h}^{-1}+$ vertical, $4.0 \mathrm{~km} \cdot \mathrm{h}^{-1}$ string thinners, $60 \% \mathrm{FB}$

Hand-thinned control, 35 DAFB

\section{'Snow Giant'}

'Loving'

Horizontal string thinner, $4.0 \mathrm{~km} \cdot \mathrm{h}^{-1}, 60 \% \mathrm{FB}$

Horizontal string thinner, $2.0 \mathrm{~km} \cdot \mathrm{h}^{-1}, 60 \% \mathrm{FB}$

Hand-thinned control, 35 DAFB

Horizontal string thinner, $60 \% \mathrm{FB}$

Hand blossom thinned, 60\% FB

Hand-thinned control, 35 DAFB

\section{'Cresthaven'}

$0.0 \mathrm{a}$
$0.0 \mathrm{a}$
$86.5 \mathrm{~b}$

Horizontal string thinner, pink

\section{'Rising Star'}

Horizontal string thinner + hand

blossom thinned, pink

Rope thinner, $80 \% \mathrm{FB}$

Hand-thinned control, 35 DAFB

$$
63.0 \mathrm{a}^{\mathrm{x}}
$$$$
51.4 \mathrm{a}
$$

$95.1 \mathrm{~b}$

$270.8 \mathrm{ab}$

$231.5 \mathrm{a}$

$326.9 \mathrm{~b}$

'John Boy'

Horizontal string thinner, $4.0 \mathrm{~km} \cdot \mathrm{h}^{-1}, 80 \% \mathrm{FB}$

Horizontal string thinner + hand

blossom thinned, $80 \% \mathrm{FB}$

Hand-thinned control, 35 DAFB

\section{'Harrow Diamond'}

Horizontal string thinner, $4.0 \mathrm{~km} \cdot \mathrm{h}^{-1}, 60 \% \mathrm{FB}$

Rope thinner, $80 \%$ FB

Hand-thinned control, 35 DAFB

${ }^{2} \mathrm{DAFB}=$ days after full bloom, $\mathrm{FB}=$ full bloom. Except where noted differently, the horizontal string thinner was operated at $2.0 \mathrm{~km} \cdot \mathrm{h}^{-1} ; \mathrm{l} \mathrm{km} \cdot \mathrm{h}^{-1}=0.6214 \mathrm{mph}$.

"1 h.ha ${ }^{-1}=0.4047 \mathrm{~h} /$ acre

'Mean separation within cultivars by Fisher's protected least significant difference at $P \leq 0.05$. total calculated yield of 'Snow Giant' peaches was reduced by string thinner treatments, while the total yields of 'Loring' and 'John Boy' were unaffected by mechanical treatments (Table 3, Fig. 2). In the 'Loring' trial, the yield of high-market-value large fruit was increased by string thinner treatments, and in the 'Snow Giant' and 'John Boy' trials, the yields of high-market-value fruit were unaffected. Some 'Snow Giant' and 'John Boy' trees were excessively thinned based on fruit load (fruit per square centimeter of limb cross-sectional area) measurements, and this suggests that a better means of assessing how many blossoms to remove should be developed. In trials conducted in 2007, yields of high-market-value peaches were increased compared with fruit from conventional hand-thinned trees (Schupp et al., 2008). Detailed 'Loring' yield data were collected at each harvest date, and early harvest yields of trees that were mechanically blossom thinned were greater than early yields of trees in hand-thinned control and nonthinned treatments (Fig. 2). Fallahi et al. (2006) also reported earlier physiological maturity of peaches from trees that were blossom thinned, and this is a potential market benefit of the early thinning that is possible with the string thinners.

ReALized ECONOMIC SAVINGS. The savings in hand thinning time and increases in fruit size realized in all trials except the 'Harrow Diamond' trial increased the economic value of the peach crops beyond that of hand thinning alone. String thinner bloom thinning costs averaged $\$ 113 /$ ha, while follow-up hand thinning costs in string-thinned plots were $\$ 139$ to $\$ 567$ per hectare compared with $\$ 610$ to $\$ 817$ per hectare in control plots (Table 4). Net positive economic impacts (realized economic savings beyond hand thinning alone) ranged from $\$ 911$ to $\$ 1368$ per hectare for the mechanical treatments tested in the early-maturing, hard-to-size cultivar Rising Star (Table 4). String thinner treatments increased net economic impacts in later cultivars by $\$ 428$ to $\$ 1115$ per hectare (Table 4). These results are consistent with those reported for the vertical string thinner (Schupp et al., 2008). The Pennsylvania orchards in these trials were managed for fresh versus processing markets. The 
Table 3. Peach fruit size, total yield, and high market value yield in six open-center system trials as affected by mechanical and hand thinning treatments in 2008 .

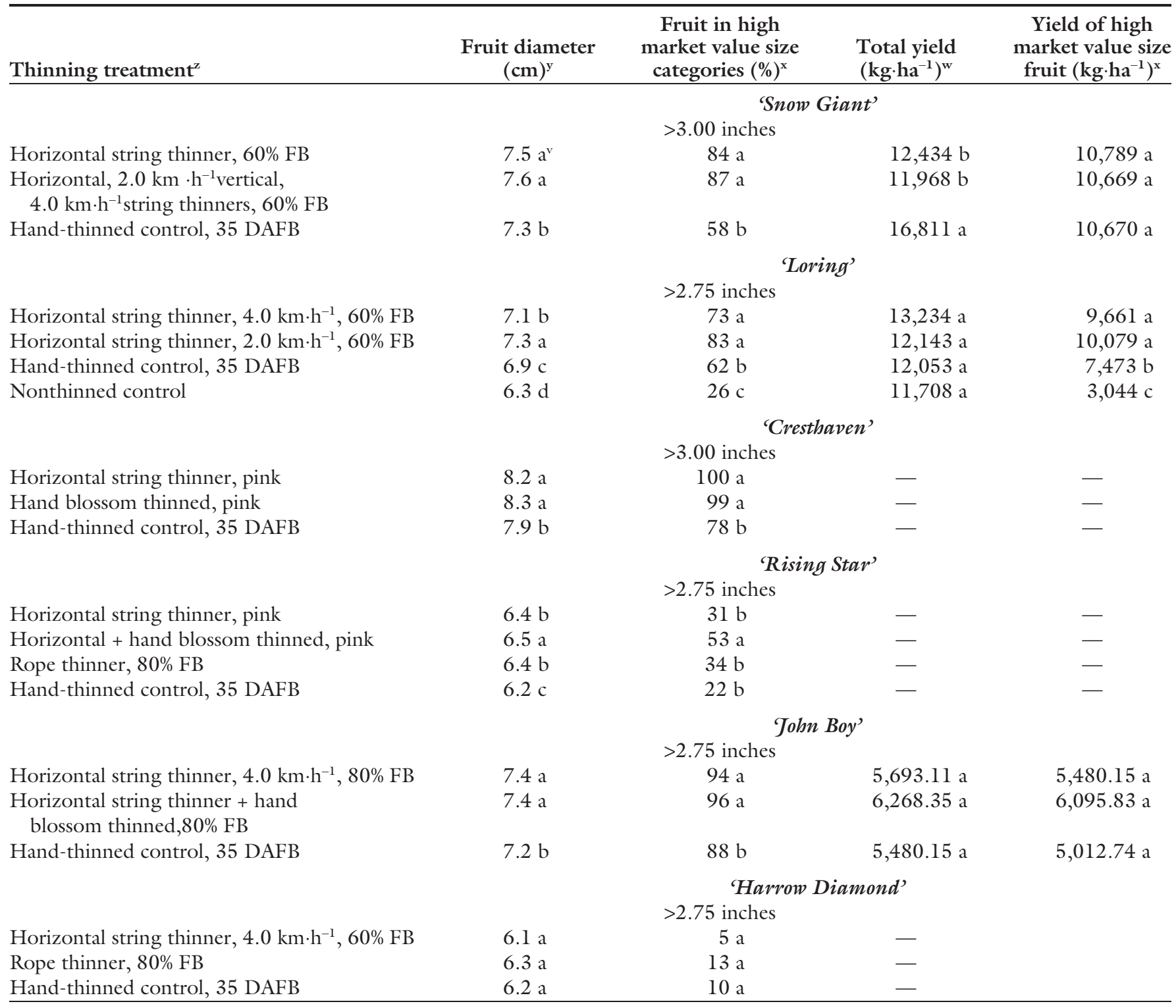

${ }^{\mathrm{z}} \mathrm{FB}=$ full bloom, DAFB = days after full bloom. Except where noted differently, the horizontal string thinner was operated at $2.0 \mathrm{~km} \cdot \mathrm{h}^{-1} ; \mathrm{l} \mathrm{km} \cdot \mathrm{h}^{-1}=0.6214 \mathrm{mph}$.

${ }^{y}$ Fruit diameter determined on 40 fruit harvested per treatment from each of six replicates; $1 \mathrm{~cm}=0.3937$ inch.

${ }^{x}$ High market value fruit were all fruit $\geq 3.0$ inches diameter for 'Sugar Giant' and 'John Boy' and all fruit $\geq 2.75$ inches for all other cultivars; 1 inch = $2.54 \mathrm{~cm}$.

"Yield calculated from fruit counts per scaffold and percentage of size distribution at harvest, with the exception of 'Loring', for which actual yield was determined; $1 \mathrm{~kg}$.ha ${ }^{-1}=$ $0.8922 \mathrm{lb} / \mathrm{acre}$.

${ }^{v}$ Mean separation within columns and cultivars by Fisher's protected least significant difference at $P \leq 0.05$.

relatively greater economic incentive for production of large-sized fruit destined for the fresh market and the comparatively high thinning labor cost for fruit destined for the processing market suggest that increased fruit size has a greater positive impact on fresh market producers, while labor savings is of greater importance for canning peach growers. However, reduced labor cost and increased fruit size are desirable goals in both production systems, suggesting that mechanical thinning will benefit fresh and canning peach growers alike.
IMPLICATIONS FOR GROWERS. The horizontal string thinner prototype reduced blossom density, crop load density, and hand fruit thinning time in five of six trials, resulting in significant reductions in labor costs for thinning. The percentage of blossom removal in open-center canopies was more variable than the percentage of removal reported previously (Schupp et al., 2008) with a vertical string thinner in perpendicular $\mathrm{V}$ canopies. The variability was most evident in orchards with variable tree shapes, pruning strategies, or canopy depths.
For example, the 'Cresthaven' trees had received detailed pruning and had gaps in their canopies that allowed the string thinner to navigate more easily through the canopies. This resulted in removal of too many blossoms. In contrast, the 'Harrow Diamond' trees had numerous overlapping branches and fewer blossoms were removed. The 'Rising Star' trees had the deepest canopies, and the string thinner was ineffective in thinning the lower canopy regions. Our research on $\mathrm{V}$-shaped canopies corroborates previous findings demonstrating the importance of 


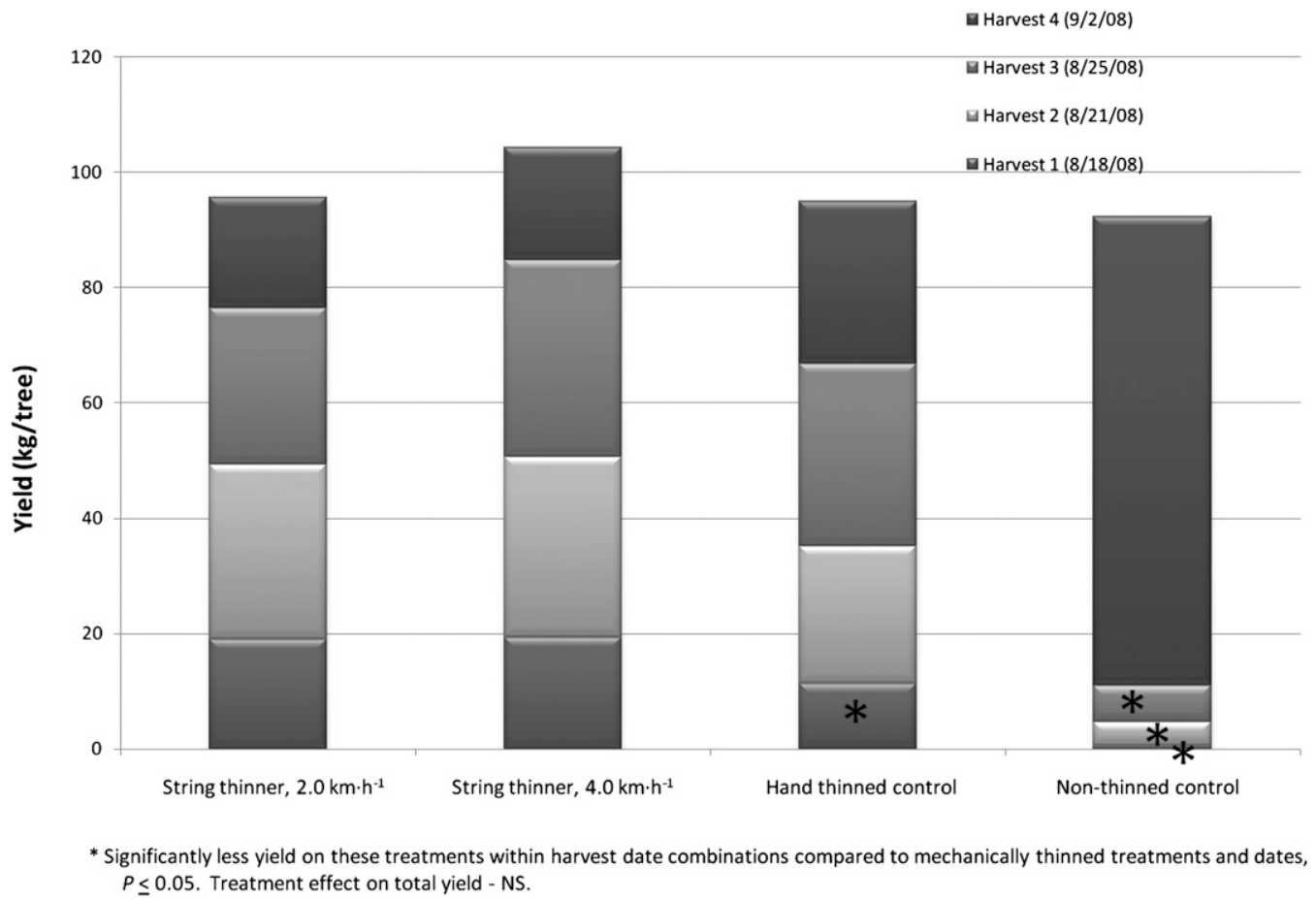

Fig. 2. 'Loring' peach yield per tree at each of four harvest dates as affected by two mechanical bloom thinning treatments compared with hand thinned or nonthinned control treatments; $1 \mathrm{~km} \cdot \mathrm{h}^{-1}=0.6214 \mathrm{mph}, 1 \mathrm{~kg}=2.2046 \mathrm{lb}$.

Table 4. Mechanical or hand blossom thinning costs, follow-up hand thinning costs, and net economic impact in five open-center system trials in commercial orchards comparing mechanical and hand thinning treatments in 2008.

Thinning treatment ${ }^{\mathrm{z}}$

Horizontal string thinner, $60 \% \mathrm{FB}$

Horizontal, $2.0 \mathrm{~km} \cdot \mathrm{h}^{-1}+$ vertical,

$4.0 \mathrm{~km} \cdot \mathrm{h}^{-1}$ string thinners, $60 \% \mathrm{FB}$

Hand-thinned control, 35 DAFB

Horizontal string thinner, pink

Hand blossom thinned, pink

Hand-thinned control, 35 DAFB

Horizontal string thinner, pink

Horizontal + hand blossom thinned, pink

Rope thinner, $80 \%$ FB

Hand-thinned control, 35 DAFB

Horizontal string thinner, $4.0 \mathrm{~km} \cdot \mathrm{h}^{-1}, 80 \% \mathrm{FB}$

Horizontal string thinner + hand

blossom thinned, $80 \% \mathrm{FB}$

Hand-thinned control, 35 DAFB

Horizontal string thinner, $4.0 \mathrm{~km} \cdot \mathrm{h}^{-1}, 60 \% \mathrm{FB}$

Rope thinner, $80 \% \mathrm{FB}$

Hand-thinned control, 35 DAFB

\section{Bloom thinning costs $(\$ / h a)^{y}$}

$\$ 128$

$\$ 194$

$\$ 116$

$\$ 243$

$\$ 128$

$\$ 296$

$\$ 37$

-

$\$ 80$

$\$ 295$

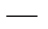

$\$ 64$

$\$ 37$
Follow-up hand thinning costs $(\$ / h a)^{x}$

'Snow Giant': 358 trees/ha

$\$ 539$

$\$ 437$

$\$ 808$

'Cresthaven': 489 trees/ha

$\$ 139$

$\$ 139$

$\$ 734$

'Rising Star': 450 trees/ha

$\$ 567$

$\$ 401$

$\$ 624$

$\$ 817$

John Boy': 612 trees/ha

$\$ 485$

$\$ 315$

\section{$\$ 610$}

'Harrow Diamond': 336 trees/ha

$\$ 1711$

$\$ 1530$

$\$ 1765$
$\$ 428$

$\$ 438$

Net economic impact $(\$ / h a)^{w}$

$\$ 1115$

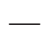

$\$ 799$

$\$ 666$

$\$ 911$

$\$ 1368$

$\$ 1027$
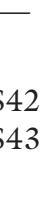

${ }^{2} \mathrm{FB}=$ full bloom, DAFB $=$ days after full bloom. Except where noted differently, the horizontal string thinner was operated at $2.0 \mathrm{~km} \cdot \mathrm{h}^{-1} ; \mathrm{l} \mathrm{km} \cdot \mathrm{h}^{-1}=0.6214 \mathrm{mph}$. y Bloom thinning costs include mechanical thinner, tractor, and labor inputs. Mechanical thinner costs were based on a 15 -year useful life of equipment and $8 \%$ interest rate. Tractor costs were $\$ 12.00 / \mathrm{h}$, equipment operator costs were $\$ 12.00 / \mathrm{h}$, and hand thinning labor costs were $\$ 8.50 / \mathrm{h} ; \$ 1 / \mathrm{ha}=\$ 0.4047 / \mathrm{acre}$.

${ }^{x}$ Follow-up hand thinning costs were based on a labor rate of $\$ 8.50 / \mathrm{h}$.

wealized economic savings defined as cost/benefit beyond hand thinning alone. Takes into account reduced hand thinning inputs and increased value of fruit in higher size categories.

${ }^{v} 1$ tree $/$ ha $=0.4047$ tree $/$ acre 
adapting tree architecture to mechanical thinning strategies (Baugher et al., 1991; Glenn et al., 1994; Schupp et al., 2008), and this is an area that will be addressed in future studies. While our studies have shown the potential benefits of a horizontal blossom thinner in traditional vase-shaped peach tree canopies, the increased speed and efficacy of mechanical thinning technology may be an incentive to hasten industry adoption of narrow canopy training systems.

Fruit size at harvest was increased by the horizontal string thinner in all but one trial. Mean fruit size of 'Loring' was greater in the $2.0 \mathrm{~km} \cdot \mathrm{h}^{-1}$ plots than in the $4.0 \mathrm{~km} \cdot \mathrm{h}^{-1}$; however, both of these treatments had the greatest percentage of fruit in highmarket-value size categories, while hand-thinned control treatments had fruit intermediate in size between mechanical blossom thinned and the nonthinned treatments. While total yields were similar for all treatments in this trial, the yield of marketable fruit from string thinned trees was over three times that of the nonthinned trees and $25 \%$ greater than the yield of hand-thinned control trees, clearly illustrating the value of reducing the competition of developing fruitlets as early as possible. The increase in fruit size associated with blossom thinning is consistent with the findings of Myers et al. (2002) and Fallahi et al. (2006).

Interest in blossom thinning of peach trees has increased in recent years due to the premium price received for large-sized fruit and the inability of costly postbloom hand thinning to consistently produce adequate fruit size. The goal of a wellmanaged blossom-thinning program is to remove $50 \%$ to $75 \%$ of the excess fruit early, making final adjustments to crop load by hand once the final crop can be assessed. Blossom thinning in the past has mainly been conducted by hand, and new string blossom thinner prototypes offer cost-effective alternatives. Tree architecture must be integrated with new thinner technology so that the economic goals of reducing the labor requirement and achieving efficient crop load management via automation, and the overall production goal of high yields with optimal size and quality, are mutually inclusive.

\section{Literature cited}

Baugher, T.A., J. Schupp, S. Miller, M. Harsh, K. Lesser, K. Reichard, E. Sollenberger, M. Armand, L. Kammerer, M. Reid, L. Rice, S. Waybright, B. Wenk, M. Tindall, and E. Moore. 2008 . Chemical and mechanical thinning of peaches. Pennsylvania Fruit News 88: 16-17.

Baugher, T.A., K.C. Elliott, B.D. Horton, S.S. Miller, and D.W. Leach. 1991. Improved methods of mechanically thinning peaches at full bloom. J. Amer. Soc. Hort. Sci. 116:766-769.

Bertschinger, L., W. Stadler, F.P. Weibel, and R. Schumacher. 1998. New methods for an environmentally safe regulation of flower and fruit set and of alternate bearing of the apple crop. Acta Hort. 466: $65-70$.

Fallahi, E., B. Fallahi, J.R. McFerson, R.E. Byers, R.C. Ebel, R.T. Boozer, J. Pitts, and P.S. Wilkins. 2006. Tergitol-TMN-6 surfactant is an effective blossom thinner for stone fruits. HortScience 41:12431248.

Glenn, D.M., D.L. Peterson, D. Giovannini, and M. Faust. 1994. Mechanical thinning of peaches is effective postbloom. HortScience 29:850-853.

Myers, S.C., A.T. Savelle, D.S. Tustin, and R.E. Byers. 2002. Partial flower thinning increases shoot growth, fruit size, and subsequent flower formation of peach. HortScience 37:623-717.

Penn State Cooperative Extension. 2008. Pennsylvania tree fruit production guide. Penn State College of Agricultural Sciences Publ. AGRS-45.

Schupp, J.R., T. Auxt Baugher, S.S. Miller, R.M. Harsh, and K.M. Lesser. 2008. Mechanical thinning of peach and apple trees reduces labor input and increases fruit size. HortTechnology 18: 660-670.

U.S. Department of Agriculture. 2008. USDA agricultural marketing service report, Appalachian district USDA fruit and vegetable market news. 1 Sept. 2008. <http://marketnews.usda.gov/portal/ fv?paf_dm=full\&paf_gear_id=1200002\& startIndex $=1 \& \mathrm{dr}=1$ \&row DisplayMax = 25\&rep Type $=$ termPriceDaily\&dr $=1$ \&loc Name $=$ \&commAbr $=$ PCH\&comm Name $=$ PEACHES $>$. 